Мср Младен Вељковић* Мср Јелена Јевтић**

Универзитет у Београду***

Филолошки факултет

докторанди
$930.85(497)$

https://doi.org/10.18485/melissa.2018.17.1.ch9

Оригинални научни рад

Примљен: 13.07.2018

Прихваћен: 11.09.2018.

\title{
ХАНОВИ И КАРАВАНСАРАЈИ НА ЦАРИГРАДСКОМ ДРУМУ ОД 15. ДО 18. ВЕКА
}

\section{Сажетак}

Пут свиле је представљао мрежу караванских путева који је повезивао Азију са Средоземљем. Једна од грана тог пута је, можемо слободно рећи, и познати Цариградски друм, који је повезивао Београд са Цариградом, у једном периоду и Будим са Цариградом. Цариградски друм (друм до Стамбола, моравски пут, царски пут итд.) био је једна од најзначајнијих саобраћајница на Балканском полуострву који је повезивао све битне центре на Балкану (Београд, Софију, Ниш, Једрене, итд). Претеча овог пута је познати римски пут Via Militaris (Војни пут), који је саграђен 33. године и који је водио рутом од Београда долином Мораве, преко Софије, Једрена до Цариграда. Овај пут су користили пролазници из различитих крајева света који су њиме пролазили са различитим циљевима: сеобе становништва, војни походи, трговина, ходочашће итд. Овим путем су се користили и Турци, који су започели своја освајања на Балкану од 14. века. У овом раду ће бити дат кратак приказ економског значаја Цариградског друма за Османски период и биће речи о стајалиштима која су се налазила дуж Цариградског друма, тј. хановима и каравансарајима. Објаснићемо и сличности између ове две врсте грађевина, које су доста блиске, али међу њима постоји и битна разлика. Што се тиче Цариградског друма, акценат ће бити на траси која је пролазила кроз територију данашње Србије.

Кључне речи: Пут свиле, Цариградски друм, каравансарај, хан, архитектура на Путу свиле, трговина.

Пут свиле представља мрежу караванских путева који је повезивао Запад са Истоком, тачније Кином. Сам назив - Пут свиле на-

\footnotetext{
* veljkovichmaki88@gmail.com

**_jelena.jevtich@gmail.com

*** Филолошки факултет, Студентски трг 3, 11000 Београд
} 
стао је у XIX веку. Немачки географ барон Фердинанд фон Рихтхофен ${ }^{1}$ је 1877. године, описујући трговинске путеве између Кине, Централне Азије и Европе, употребио сложеницу Seidenstraße (нем. Пут свиле). ${ }^{2}$

Овај израз је у науци усвојен како на Западу, тако и у Кини и Јапану. Главни артикал по коме су ови каравански путеви добили назив - свила преношена је разним путевима и самим тим је постала симбол везе Запада и Истока. Овај израз био је далеко од тога да изражава суштински карактер промета робе, јер је путевима и караванским стазама пролазило мноштво људи који су поред свиле превозили и другу робу. ${ }^{3}$ Осим копненог пута, постојао је јужни, поморски пут који је преко југоисточне Азије повезивао Африку и јужну Азију са Кином. ${ }^{4}$

Пут свиле није био само пут којим се трговало свилом, већ и чајевима, зачинима, папиром, коњима, порцеланом, барутом, шириле су се разне идеје из области науке, и религије, почевши од будизма, хришћанства, тј. несторијанства и ислама.

Настанак Пута свиле се везује за повезивање Кине са Централном Азијом у I веку пре нове ере, када је генерал династије Хан (206. године пре нове ере - 260. године нове ере), Чанг Ћиен, добио задатак да створи савез против Хуна. Била је то једна од многих војних мисија у централноазијске престонице, чак до Самарканда, Бухаре, Андхуја, Херата, Шириза и Исфахана. Сврха тих мисија била је да се издејствује савез. Генерал Ћиен се са своје мисије вратио 138. године пре нове ере у престоницу Чанган (данашњи Сиан). ${ }^{5}$

Пут свиле био је један од неколико праваца којима је 126. године пре нове ере Чанг Ћиен поново путовао у потрази за чувеним ферганским коњима који би били употребљени у борби против Хуна. Поред свиле и коња, тим путем је била обављана трговина, како је горе споменуто, мноштвом друге робе. Каравани који су се кретали ка Кини преносили су злато и друге драгоцене метале, вунене и плат-

Фердинанд фон Рихтхофен (1833-1905) немачки географ и истраживач, стриц Манфреда фон Рихтхофена, немачког пилота из Првог светског рата, познат као Црвени барон.

2 https://de.wikipedia.org/wiki/Seidenstraße

3 Оксрордска историја ислама, прир. Џ. Л. Еспозито, Београд, 2001, 458.

4 Исто.

5 Исто, 460. 
нене тканине, слоновачу, ћилибар, корале, нефрит и друге ретке минерале, азбест и стакло. Терет каравана из Кине садржао је мноштво разноврсног бронзаног оружја и оруђа, гвожђе, крзна, грнчарију, керамику, цимет и равен. ${ }^{6}$

Чувени пут полази из Чангана (данашњи Сиан), пролази познатим Хекси коридором у Гансуу на северозападу до Дунхуанга на ивици пустиње Гоби. Од Дунхуанга пут је пролазио кроз чувену Жад капију, а онда се рачвао у северни и јужни крак, обилазећи непроходну пустињу Такла-Макан и пратећи оазе, које воду добијају од глечера, у подножију Тјеншан планина на северу и на обронцима Хималаја и Памира на југу. Ти обилазни путеви се у Кашгару поново спајају у један главни пут који води ка западу преко Коканда, Самарканда, Бухаре, Мерва, Ирана (Персије) и Ирака до обале Средоземног мора и Анадолије, док јужни и северни путеви скрећу ка Индији и Русији. ${ }^{7}$

У овом раду главни акценат је стављен на тзв. Цариградски друм, који, можемо слободно рећи, представља једну грану трговачког пута на Путу свиле. Ова два трговачка пута била су повезана преко Цариграда, у који је роба стизала караванима који су се кретали из Ирана преко Анадолије.

Анадолија је у XIII веку постала главна трговинска спона између Истока и Запада. Анадолија није само повезивала западну Европу са Истоком, већ се преко ње обављала трговина у правцу север и југ, и тиме повезивала источну Европу и арапске земље. ${ }^{8}$ У том периоду градови централне Анадолије постају значајни трговински центри (Сивас, Кајсарија, Коња, Амасија и Анкара). ${ }^{9}$

Порастом Османске моћи у XIV веку, центар трговине се полако сели у западну Анадолију. Овим премештањем долази и до промене у сплету трговачких путева. ${ }^{10}$ Главни град тадашње Османске државе, Бурса, ${ }^{11}$ постаје најважнији трговачки град Анадолије и велики центар за

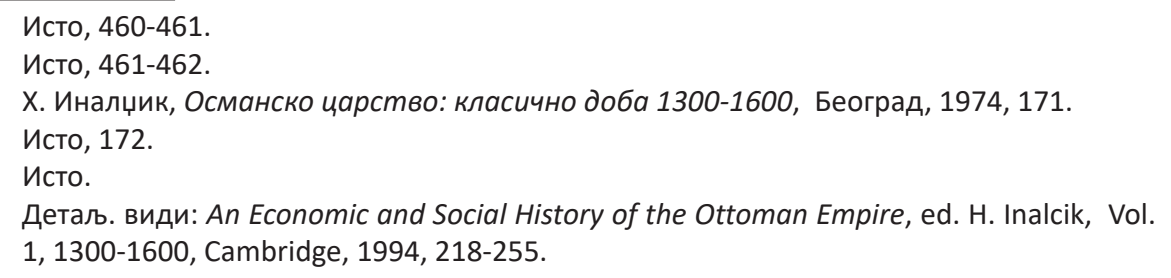


размену робе између Истока и Запада. Свила, која је била главни артикал и због кога је Пут свиле добио назив, чинила је основу развоја и напретка Бурсе, па и самог Османског царства које у XIV веку креће у ширење своје територије, у Европи, тј. Балканском полуострву и Анадолији. ${ }^{12}$ Чак и после премештања седишта османске власти у Цариграду 1453. године, Бурса није изгубила на значају и остала је важан трговински центар још стотинак година. ${ }^{13}$ Сем свиле, у Бурсу су пристизали мошусов мирис, равен и кинески порцелан, што је представљао највећи део робе који је пристизао из централне Азије, док су персијски трговци односили европске вунене тканине, бурсанске брокете, кадифу, златни и сребрни новац који је имао већу вредност у Ирану. ${ }^{14}$ Поред ових артикала треба још споменути и шафран, бибер (у једном периоду сматран „црним благом“), материје за боју и разне тканине. ${ }^{15}$

Постепеним ширењем Османског царства од XIV до XVI века, ${ }^{16}$ нова престоница царства - Цариград постаје политички и трговачки

12 Х. Иналџик, Османско царство, 173.

13 Исто, 174.

14 Исто.

15 Исто, 175.

16 После освајања Цариграда 1453. године од стране Мехмеда II Освајача (1444$1446 ; 1451-1483)$ Османско царство је учврстило положај као најмоћније силе у југоисточној Европи и источном Средоземљу. Током његове владавине совојена је Српска деспотовина 1459. године, Босна 1463. године, а за време владавине његовог наследника Бајазита II (1481-1512) пала је Црна Гора 1496. године. Током XV и XVI века Османско царство је ушло у период совајања и проширења, померивши своје границе дубоко у Европу и северну Африку. Економија државе је цветала јер је Османско царство држало под контролом главне копнене трговинске путеве између Европе и Азије. Царство је напредовало под владавином низа енергичних и успешних султана. Султан Селим I (1512-1520) је, за своју кратку владавину, проширио границе на југу и истоку. Успоставио је Турску владавину у Египту, а Мека и Медина, центри исламске вере, постали су део Османског царства и султан је добио титулу халифе. Његов наследник Сулејман I Величанствени (1520-1566; познат и као Законодавац) додатно је проширио границе царства. Након заузимања Београда 1521. године, Турци су започели освајање Угарске. После битке на Мохачу 1526. године, Сулејман I је загосподарио територијом јужне Угарске (само је северни део Угарске остао непокорен) и продро до Беча 1529. године, али га није освоји. Војне операције ка Бечу поново су покренуте 1532. године, али и овог пута без успеха. После другог неуспеха освајања Беча и освајањем Будима 1541. године, Турско продирање дубље у Европу је заустављено. Османско царство је остала доминатна сила и у наредним вековима, али, почевши од XVIII века њена моћ слаби. Османско царство ће у XIX веку изгубити статус велике силе и нестати са историјске сцене почетком XX века. Историја османског царства, прир. Р. Мантран, Београд, 2002, 93-138; 165-188. 
центар царства. Цариград је био крајњи циљ трговачких путева. У Османску престоницу пристизали су каравани из Ирана, Басре и Алепа. Из Цариграда су, како је на основу свог истраживања о овом периоду Османске историје забележио историчар Халил Иналџик, свака „три месеца каравани одлазили за Иран и централну Азију... по један караван годишње је стизао из Дубровника, месечно један из Пољске, а недељно један из Смирне“. ${ }^{17}$

Освајањем Балканског полустрва, Османско царство је загосподарило трговинским путевима који су повезивали Балканско полуострво са Цариградом. Први је био Via Egnatia, који је полазио из лука које се налазе на данашњој територији Албаније и пружао се преко Охрида, Битоља и Солуна. Други је био пут који води из доњег Подунавља преко Тунџанске долине и Једрена. И трећи, који је централна тема овог рада, био је тзв. Цариградски друм, који је повезивао Београд са Цариградом, а касније Будим са Цариградом. ${ }^{18}$

Tраса Цариградског друма представља главну линију комуникације, како у прошлости тако и данас, на Балканском полуострву која повезује Србију са суседним балканским државама: Бугарском, Грчком и Турском. ${ }^{19}$ Због свог положаја, ова линија комуникације Моравском долином, преко нишавске и маричке, избија на Цариград, преко вардарске на Егејско море, а Савом и Дунавом повезана је са средњом Европом. ${ }^{20}$ Пут је у различитим периодима имао различите називе. Римљани су овај пут називали Via Militaris, Via Publica, agger publicus, strata, у средњем веку се звао царски или моравски пут, у Осамнском периоду јавни пут или царски пут, у дубровачким архивима се спомиње као via del Belgradi, а код нас цариградски пут или друм, друм до Стамбола, џада велика или велики друм. ${ }^{21}$ За ову линију комуникације у XVI веку користи се и назив Via Traiana. ${ }^{22}$

17 Х. Иналџик, Османско царство, 206.

18 Исто, 207.

O. Zirojević, Carigradski put (drum), Helšinska povelja 167-168 (2012), 63.

О. Зиројевић, Цариградски друм од Београда до Софије (1459-1683), Зборник Историјског музеја Србије 7, Београд, 1970, 20.

21 Исто, 21.

22 Детаљ. види: М. СТ. Поповић, Од Будима до Константинопоља: Via Traiana у светлу путописне литературе од 14. до 16. века, Нови Сад, 2017, 41-46. 
Значај ове кумуникације први су искористили Римљани. Први пут су изградили долином Мораве 33. године, који су проширили на исток, кроз тадашњу територију Тракије, између 29. и 61. године. ${ }^{23}$ Пут који су римљани изградили ишао је од Београда (Singidunum) десном обалом Дунава до Костолца (Viminacium), одатле је скретао према југу на Медвеђу (Idimmum), Ћуприју (Horeum Margi), Бован (Praesidium Pompei) и Ниш (Naissus). Од Ниша пут је ишао преко Беле Паланке (Remesiana) и Пирота (Turres) на Софију (Serdica). После Софије пут је ишао преко Пловдива (Philipolisa) до Једрена (Hadrianopolisa) и на крају до Цариграда. ${ }^{24}$ Током средњег и новог века овај пут је остао главна комуникација и правац пута углавном се поклапао са горе споменутим римским. ${ }^{25}$ Међутим, током свог проласка кроз Балкан 1433. године, Бертрандон де ла Брокијер ${ }^{26}$ је пролазио трасом пута која је ишла из Ниша преко Крушевца, па одатле кроз Шумадију за Београд. ${ }^{27}$ Овим правцем ће ићи и хришћанска војска 1443. године током Дуге војне. ${ }^{28}$

За време Османског царства овај пут је постао главна привредна артерија на Балканском полуострву. Сва роба која је стизала у Цариград даље се транспортовала до Београда и назад. Током своје владавине на Балканском полуострву Турци су изградили низ путева који су били повезани Цариградским друмом и тако стоврили мрежу путева. ${ }^{29}$ Међутим, овом приликом акценат је на главну трасу пута од Београда до Софије, и неће бити споменута сва насеља дуж пута.

У грубим цртама, пут је почињао од Београда (пао под османску контролу 1521. године) па до Гроцке, где се рачвао. Један крак је

О. Зиројевић, Цариградски друм од Београда до Софије, 20 Исто, 21.

Исто.

Бертрандон де ла Брокијер (1400(?)-1459) био је бургундски путописац и високи чиновник на двору Филипа Доброг, војводе Бургундије (1396-1467). Он је између 1432. и 1433. године пропутовао Блиски исток, Малу Азију и Балканско полуострво. На захтев свога господара, саставио је књигу о своме путовању под насловом Путовање преко мора. Његово дело сматра се значајним историјским извором за период Османског освајања Балканског полуострва. 
продужио ка Смедереву, а други ка југу према Коларима. Од Колара се даље ишло до Хасан-пашине Паланке (данашња Смедеревска паланка) па одатле на Баточину, Јагодину, Параћин, Ражањ, Алексинац до Ниша. Од Ниша до Софије се ишло преко Беле Паланке, Пирота и Димитровграда (стари назив Цариброд). ${ }^{30}$ Од Софије пут је ишао преко тзв. Трајанових врата, која се налазе близу града Ихтиман до Пловдива. Од Пловдива се даље ишло до Черномена па одатле до Једрена. Последња етапа пута ишла је од Једрена, Хаваса, Бабаескиа, Лулебургаза, Друзипара, Чорлуа до Цариграда. ${ }^{31}$

После освајања Будима 1541. године траса пута је знатно продужена. Овај део пута је у почетку био намењен у војне сврха, а касније и у привредне. Каравани су преносили европску робу на југ и обрнуто. Производи из Османског царства и са Истока, првенствено мириси, зачини, разне тканине допремани су на тржишта Европе. ${ }^{32}$ Овај северни део Цариградског друма је ишао од Београда до Вуковара, где су постојале две трасе пута: прва се држала углавном обале Дунава, а друга је ишла преко Сремске Митровице (више се користила ова траса пута). Од Вуковара пут је ишао северније до Осјека, Дарде, Мохача, Батаскеа, Јени Паланке. Од Јени Паланке се ишло до Толуна, Фелдвара, Хамзабег Сараја и на крају до Будима. ${ }^{33}$

Пролазећи кроз Османско царство, путници и трговци су на путу наилазили на коначишта дуж караванских путева. Најчешћа коначишта, истовремено и најраспострањенија, била су ханови и каравансараји. ${ }^{34}$ Заједно са ширењем Османске државе на Балканском полуострву, истовремено се ширила и оријентална култура и архитектура. У исламском свету се, од ранијих времена, одвојио посебан тип архитектуре тзв. трговачка архитектура..$^{35}$ Њој су припада-

30 О. Зиројевић, Цариградски друм од Београда до Coфuje, 21-41; O. Zirojević, Carigradski put (drum), 64.

31 М. Ст. Поповић, нав. дело, 110-113, 128, 140-141.

32 О. Зиројевић, Цариградски друм од Београда до Будима у XVI и XVII веку, Нови Сад, 1976, 3.

33 Исто, 4-7.

34 Е. Миљковић, На раскршћу епоха, Студије из историје српског народа под османском влашћу, Ниш, 2013, 116-117.

35 М. Кочић, Оријентализација материјалне културе на Балкану, Османкси период XV-XIX век, Београд 2010, 37. 
ли каравансараји, ханови, мостови, безистани и дућани који су били намењени привредним активностима, у првом реду трговини. ${ }^{36}$ Ове грађевине су од Персиајнаца преузели Турци Селџуци и проширили је у Анадолији у XI веку. Архитектонске традиције Селџука наставили су Османлије који су овај тип архитектуре довели до врхунца у периоду XVI и XVII века. ${ }^{37}$ Они су до те мере користили овај тип зграда да су у изворима, како је запазила историчар Марија Коцић у својој књизи о оријентализацији материјалне културе, са краја XVI били познати по „грађењу купатила, чесми, мошеја и каравансараја“.38 У нашим крајевима се до краја XVI века сва коначишта називају каравансарајима, нараво користи се назив и хан, али ће у каснијем периоду, тачније од XVII века па надаље, овај други термин остати у употреби. ${ }^{39}$ Сведочанства о томе налазе се како у белешкама путописаца који су пролазили кроз наше крајеве, тако и у топонимима. Велики број локалитета носи у називу лексему хан или корен хан- : Хан, Ханиште итд. ${ }^{40}$ Са припајањем балканских крајева Османском царству нарасла је и фреквентност саобраћаја у овим крајевима. Каравансараји и ханови почињу се подизати како уз главне, тако и споредне друмове у мањим и већим насељеним местима. ${ }^{41}$

У историографској литератури, како наводи Ема Миљковић, није сасвим разрешена разлика између ханова и каравансараја. ${ }^{42}$ Наиме, само донекле је тачно да су хан и каравансарај синоними. ${ }^{43}$ Најпре можемо навести то да су обе речи до нас дошле из персијског језика посредством турског, како је горе споменуто, и обе означавају зграду за коначење путника. Како наводи Хамдија Крешевљаковић у свом истраживању, разлика је у томе што је „у хану путник плаћао за храну и огрев, док је у каравансарају имао бесплатно преноћиште, а

36 Исто, 38.

37 N. Smailagić, Klasična kultura islama, knj. 2, Zagreb, 1976, 419-421.

38 М. Кочић, нав. дело, 38.

A. Bejtić, Spomenici osmanlijske arhitekture u Bosni i Hercegovini, Prilozi za orijentalnu filologiju III-IV, Sarajevo, 1953, 270; О. Зиројевић, Цариградски друм од Београда до Cофије, 51; Е. Миљковић, нав. дело, 117. 
за храну и све остало морао се сам побринути“. ${ }^{44}$ Поред тога, хан је поседовао намештај, тј. одређени инвентар, док у каравансарају тога није било. ${ }^{45}$ Сараји ${ }^{46}$, односно дворови, у којима су одседали каравани јесу монументалнији од ханова. Узрок овоме је то што су подигнути на врхунцу моћи османског царства па је самим тим у њихову изградњу уложено више средстава. ${ }^{47}$

Неки аутори подвлаче различит карактер економске организације хана и каравансараја. Тако Хамдија Крешевљаковић и Алија Бајтић истичу да је хан предузеће, а каравансарај пре свега хуманитарна установа. ${ }^{48}$ Један француски путописац, описујући своје путовање српским земљама 1573. године, наводи да је стигао у „Таслиџе, где се задржао у великом и мрачном хану, покривеном оловом, који је саградио Мехмедпашин син.“" 49 Међутим, овај исти путописац касније наводи у свом другом писму из Пљеваља да је коначио у каравансарају. ${ }^{50}$

Будући да су и савременици мешали ова два типа грађевине (чак су и мешана у званичним документима Османског царства), можемо само донети закључке о великој сличности, али и различитом стилу градње у зависности од поднебља, као и средстава.

Хамдија Крешевљаковић ханове разврстава на следећи начин:

1. Ханови уз путеве. У овим хановима путници су се најчешће задржавали само по једну ноћ јер никоме није било у интересу да прокрастинира са скупим и временски дугим путовањем. Изузетак су били хладни зимски дани, када би снег завејао путеве. Дешавало се да се путник задржи уколико би у хану затражио хитно лечење, а неке од путника су у хану подлегли болести која их је затекла на путу.

2. Трговачки ханови. Налазили су се у већим трговачким центрима. У њима су трговци одседали знатно дуже, чак и по неколико месеци. Боравак у овим хановима користили су да

44 Исто.

45 Детаљније о инвентару хана види: Х. Крешевљаковић, нав. дело,

46 Сарај у сложеници каравансарај означава како кућу и коначиште, тако и двор.

47 Е. Миљковић, нав. дело, 117.

48 Исто.

49 Исто, 119.

50 Исто. 
би трговали, размењивали и набављали робу. Било је и оних који нису имали породицу те су били трајни станари у хану.

3. Сезонски ханови. У њих су путници долазили да се лече, као и на теферич (излет или весеље). ${ }^{51}$

У местима у којима је било више ханова могла се уочити разлика у рангу ханова. Тако су у једним хановима одседали богатији путници, припадници вишег сталежа, док су у другим коначиште тражили сиромашнији путници и сељаци. ${ }^{52}$

Сваки хан имао је ханџију и бар по једног слугу..$^{53}$ Међу особљем у већим хановима послови су били раздељени на: кафеџију, одаџију, подрумџију и евентуално и друге слуге.

Ханџија изнајмљује хан и намештај који се у њему налази. Он опрема хан и запошљава особље, којим руководи. Брине се за снабдевање хана потребном робом и намирницама, а такође управља финансијама. У мањим местима и у хановима уз путеве ван насељених места јело се правило у ханџијиној кући. У великим местима постојале су засебне ашчинице у које су путници одлазили ради оброка. А понеки већи хан имао је договор са ашчијом о томе да слуга хана или ашчијин шегрт доставе храну путницима и кириџијама у хану. ${ }^{54}$

Уколико је храна била приправљана у самом хану, спремала ју је или ханџијина супруга или за то посебно ангажована куварица ашчикадуна. Најчешћа јела на ханској трпези била су: чимбур, печена телетина, печена пилетина, пилав, пита, цицвара, сир, кајмак. ${ }^{55}$

Одаџија је био собар у савременом смислу те речи. Његова основна дужност била је ложење ватре и грејање соба. Постојале су две врсте пећи. Старије и савременије. Старије су се ложиле из ходника, а савременије су имале врата у самој соби. Одаџија се такође старао о расвети у ходнику и у собама хана. Такође је у његовој надлежности било проналажење праље која би одржавала постељину и прала рубље гостију. ${ }^{56}$ О коњима гостију и њиховој прехрани старао се

Исто.

Исто.

Исто.

Исто 271. 
подрумџија. Поред тога, његове дужности обухватале су чишћење дворишта и отварање и зтварање капије. Капија се затварала два сата по заласку сунца, а ујутру отварала мало пре зоре. Капија се није смела отворити док се сви не пробуде и утврде јесу ли им ствари на броју. ${ }^{57}$

Кафа се почела пити по хановима најраније у седамнаестом веку. Уколико је хан био мањи, ханџија је уједно био и кафеџија, а у већим хановима ова дужност била је засебна. Кафеџија је пекао кафу, припаљивао чибуке и разносио кафе по собама. У ханове који су се налазили по насељеним местима свраћало је и локално становништво на кафу и разговор. На овим местима размењивала су се искуства са путовања и информације. У појединим хановима, нарочито зими, могле су се чути јуначке песме уз звуке тамбуре и гусала. ${ }^{58}$

Путнике је увек дочекивао и испраћао неко од запослених у хану. Угледнији, тј. виђенији гости имали су част да их дочека сам ханџија. Поздрав који је ханско особље узвикивало при дочекивању госта био је: „Ноš geldum“ (добродошао), а приликом растанка: „Ugurula“ - сретно! Најбоља могућа услуга се подразумевала, а поред тога пажња се посвећивала и лечењу путника. ${ }^{59}$

Каравансараји јесу најзначајнија тековина иранске архитектуре. ${ }^{60}$ Расути дуж Пута свиле били су простор контакта, тачке пресека у делти путева између градова. У потрази за одмором и окрепљењем, ради заштите имовине и животиња са којима су путовали, путници су у њима проналазили заклон. Служили су дипломатама, ходочасницима, трговцима као одморишта. Као стециште путника са различитих одредишта која је обухватао Пут свиле, били су погодно место за размену идеја, културних утицаја и робе из међусобно удаљених крајева. ${ }^{61}$

\footnotetext{
57 Исто.

58 Исто 270-271.

59 Х. Крешевљаковић наводи одломак из путописа М. Мажуранића у коме даје опис суочавања са тешким временским приликама и како је захваљујући заједничкој помоћи Милице и њеног супруга, православаца, и ханџије муслимана избегао смрт у снегу. Х. Крешевљаковић, нав. дело, 271.

60 H. E. Sangari, A. Shahamipour Morphology of Caravanseraies in Iran's Safavid Era, Ciência e Técnica Vitivinícola, Vol. 29, No. 8, 2014, 156.

61 H. Hamrahi, Z. K. N. Manshad, Comparison of Caravanserai of Azerbaijan and Isfahan Based on Ghanli Bolagh Caravanserai in Ardabil and Madar Shan Caravanserai in Isfahan, American Journal of Art and Design, Vol. 2, No. 1, 2017, 31.
} 
Реч каравансарај по пореклу је сложеница и састоји се од речи: караван- и -сарај. Караван означава групу људи која путује, групу путника, а сарај означава гостионицу, крчму, односно свратиште. ${ }^{62}$ Основна специфичност јесте централно двориште, које се налази у центру грађевине и зидом је заклоњено од налета пустињског ветра и наноса песка. Каравансарај је тако коначиште за групу путника у пустињским пределима Азије, Северне Африке и, шире узев, дуж Пута свиле. Језик из кога ове речи потичу јесте пехлеви. ${ }^{63}$

Са изградњом првих каравансараја почело се још у доба Ахменидског царства. ${ }^{64}$ Спектакуларни период Првог персијског царства што се архитектуре тиче изнедрио је величанствене градове као што су Персепољ, Суза и Екбатан. Експанзија царства имала је за последицу то да је велика пажња посвећена и изградњи путева који су повезивали ове градове. Они су се простирали од Кавказа до Персијског залива и од Централне Азије до Анатолије, Медитерана и Северне Африке. Један од најважнијих путева водио је од Сузе до Ефеса и био је дуг 2683 километра. На путу се налазило 111 станица, од којих је свака имала одморне коње које би путник могао преузети наместо свог коња. Ове станице међусобно су у просеку биле удаљене између 30 и 40 километара. Са даљом изградњом путева наставило се и у Партском ${ }^{65}$, као и у Сасанидском царству ${ }^{66}$, која су наследила ахменидско. За сваку од ових државних творевина пут је био од виталне важности зато што је представљао везу Истока и Запада, и зато што се основна економска делатност одвијала управо на њему. Био је један од основних извора прихода и економске стабилности. Због тога је одржавање пута и трајно побољшавање услова путовања и безбед-

\footnotetext{
62 Х. Крешевљаковић, нав. дело, 266.

63 Југозападни Ирански језик, спада у средњеиранске језике. Језик је средњеперсијске династије Сасанида (III-IV) на коме је написана богата зороатријска и манихејска књижевност арамејским и манихејским писмом.

Ахменидско царство или Прво персијско царство, тј. Староперсијско царство било је прво персијско царство и обухватало је област великог Ирана у периоду од 520. п.н.е. до 330. п.н.е.

Партска царевина била је античка држава на Блиском истоку у периоду између 3. в.п.н.е. до 3.в.н.е.

66 Сасанидског царство или Сасанидска персија била је иранска држава под династијом Сасанида од 226. до 651.
} 
ности, као и каравансераја, као коначишта и места сусрета, било приоритет сваког од ових царстава. Ширење ислама, успостављање Умајадског ${ }^{67}$ и Абасидског калифата ${ }^{68}$, као и суверенитет Кине, додатно су ојачали везе источних и западних земаља на Путу свиле и још више олакшали саобраћај. ${ }^{69}$ Политичка, економска и културна размена још више се раширила и учврстила. ${ }^{70}$

Ера Сасанида представља златно доба архитектуре Ирана. За владавине ове династије обновљени су оронули каравансераји и подигнут је велики број нових каравансараја као и цистерни дуж Пута. ${ }^{71}$

Кравансарај чинили су: одаје за преноћиште, кухињу, цистерну, оставе за робу, стаје, одаје за складиштење сена, тј. прехране за животиње, обућарска, радња, библиотека, месџид. Путници и њихове животиње могли су затражити помоћ у овим станицама, а све финансијске трошкове сносили су вакуфи. ${ }^{72}$

Каравансарај је симетрична зграда, са монументалним вратима, пластично украшеним орнаментима. У средишту је обавезно двориште. Из далека изгледа као дворац опасан зидинама. Неретко је двориште било укопано испод нивоа терена да би се одржавала нешто нижа температура, односно већа свежина, у односу на околину. ${ }^{73}$

Путујући у пролеће 1574. године кроз Херцеговину, Француз Пјер Лескалопије описао је каравансараје следећим речима: „Каравансараји су склоништа где отседају и богати и сиромашни зато што немају ништа боље. То су као велике шупе: светлост, уместо кроз прозоре, улази на отворе; немају тавана, наго су само кровом покривене. Унутра, свуда уоколо су узвишења, висока две и по стопе,

67 Умајадски или Омејадски калифат други је од четири велика калифата утврђена после Мухамедове смрти. Калифат је на врхунцу обухватао територије од Кавказа до Магреба и Иберијског полуострва.

68 Абасидски калифат је трећи велики калифат по реду, утврђен након смрти пророка Мухамеда.

69 H. Hamrahi, Z. K. N. Manshad, Comparison of Caravanserai of Azerbaijan and Isfahan, 31.

70 Исто.

71 Исто.

72 G. Büyükmıhçı, Caravanserais: the Architectural Treasures of Silk Road and the Case of Kayseri-Sultanhani, Archi-cultural Translations Through the Silk Road: 2nd International Conference : Selected Papers : Mukogawa Women's University, Nishinomiya, Japan, July 14-16, 2012, 358.

73 А. Bejtić, нав. дело, 269. 
широка седамс стопа, на која се пењу људи да би лежали одвојени од коња; ови су везани уз господара за гвоздене алке причвршћене на узвишењима, тако да свако види свог коња поред себе и ставља храну на узвишење... Изнад ових уздигнутих места, свуда уоколо на зидовима су куке, где свако веша своје ствари без бојазни да ће било шта изгубити, јер ујутру каравансараџија, тј. домаћин, не отвара врата док све не обиђе и сваког не упита да није шта изгубио“. ${ }^{74}$

На траси пута од Београда до Софије прво ћемо споменути коначиште у Смедереву. У овом граду је, због свог значаја, било неколико каравансараја, али у XVI веку се спомиње само један. Следеће коначиште је био велики каравансарај у Гроцкој, а у Коларима се налазио хан. У Хасан-пашиној Паланци постојао је каравансарај, али у каснијем периоду путописци наводе два мала каравансараја. Постојао је један велики каравансарај у Баточини, међутим, у каснијем периоду путописац Евлија Челбија ${ }^{75}$ овде је затекао један хан. На следећој станици караванског пута, Јагодини наилазимо на један проблем. Наиме, извори се не слажу око тачног броја коначишта у овом месту. Једни наводе један карвансарај, други четри каравансараја, пак касније се спомињу само два каравансараја. Евлија Челебија наводи да у Јагодини има више ханова. У Параћину се налазио каравансарај, а у Ражњу хан. Између Ражња и Алексинца био је изграђен један каравансарај у ишчезлом селу Смољановцу. У Алексинцу путници су смештај налазили у једном каравансарају. Између Алексинца и Ниша, био је изграђен хан у Муса-пашиној Паланци. У Нишу је постојало неколико каравансараја на почетку XVI века. Следеће коначиште је било у Пироту где је постојао каравансарај. На последњој траси пута до Софије последње коначиште се налазило у селу Драгоману. ${ }^{76} \mathrm{Ha}$ крају овог дела пута, у Софији је постојао један каравансарај. ${ }^{77}$ Што се

74 Д. Ђурић Замоло, Београд као оријентална варош под Турцима 1521-1867, Београд, $1977,80$.

75 Евлија Челебија је један од најславнијих отоманских путописаца. Његови путописи су од великог значаја за историографију поготово део који је везан за југословенске земље. Рођен је 1611. у Истанбулу, а умро 1682. године у Египту. О његовом путопису види: Е. Čelebija, Putopis, Odlomci o jugoslovenskim zemljama, Prevod, uvod i komentar napisao Hamiz Šabanović, Sarajevo, 1979.

76 Исто, 51-54.

77 Турски споменици, књ. І, св. I, 1348-1520, Beograd, 1940, 437. 
тиче дела од пута од Софије до Цариграда навесћемо пар коначишта: у Пловдиву се налазио велики хан који јебио познат под називом Куршум хан, ${ }^{78}$ а између Пловдива и Једрена путници су могил да нађу коначиште у два велика хана (један се налазио у Папазли близу реке Мрице, а други у Узунџи). ${ }^{79}$

На путу од Београда ка Будима прво каначиште налазило се у Земуну. Овде су у XVII веку постојала два хана (касније ће бити три). Код села Прахова налазио се један каравансарај. У Сремској Митровици постојао је средимон XVI века каравансарај, а у XVII веку овде су постојала три хана. Између Сремске Митровице и Вуковара постојао је један хан који се налазио у Товарнику. У Вуковару је постојао каравансарај, а у XVII веку ту су била три хана. На следећој станици караванског пута, у Осјеку, постојало је шест ханова и један каравансарај. У Јени Паланци је постојао један мали хан. У месту Толна у другој половини XVI века постојао је каравансарај. У Фелдвару је постојао хан, а на последњем стајалишту пред Будим, у Хамазбеговом Сарају каравансарај. ${ }^{80}$

78 https://bulgarianhistory.org/kurshum-han/

79 М. Ст. Поповић, нав. дело, 165.

80 О. Зиројевић, Цариградски друм од Београда до Будима, 16-18. 


\section{Mladen Veljković Jelena Jevtić}

\section{HANS AND CARAVANSERAIS ON TSARIGRAD ROAD FROM 15TH TO 18TH CENTURY}

\section{Summary}

Silk Road represented a network of caravan roads that linked East Asia with the Mediterranean. One of the branches of this road was the famous Tsarigrad Road, which connected Constantinople with Belgrade.

Tsarigrad Road (Road to Istanbul, Moravian Road, imperial road, Great Road) was one of the most important roads on the Balkan peninsula that connected all important centers in the Balkans (Belgrade, Sofia, Nis, Edirne, etc.). The precursor to this road was the famous Roman road Via Militaris (Military Road), which was built in the 33rd year of a new era, which led the route from Singidun to the valley of the Morava, through Sofia and further to Asia Minor. This road was used by passengers from different parts of the world who passed through it with different goals: migrations, military campaigns, trade, etc. This route was also used by the Turks, who started their conquests in the Balkans in the 14th century. This paper will give an overview of the economic significance of the Tsarigrad Road for the Ottoman period and will be about the stands that were located along the Tsarigrad Road, hans and caravanserais. We will also explain the similarities between these two types of buildings, which are rather close, but there is also a significant difference between them. As for the Tsarigrad Road, the focus will be on the route that went through the territory of today's Serbia.

Key words: Silk Road, Tsarigrad Road, caravanserai, han, architecture on the Silk Road, trade. 